\title{
4-6 Yaş Grubu Çocukların Sosyal Becerileri ve Teknoloji Kullanımları Arasındaki İlişkinin İncelenmesi1
}

\section{Investigation of the Relationship between Social Skills and Technology Uses of 4-6 Year Old Children}

\author{
Fatma ÖZCAN², Atila ÇAĞLAR ${ }^{3}$, Serpil PEKDOĞAN ${ }^{4}$
}

\section{Öz}

Bu araştırmanın amacı okul öncesi eğitime devam eden 4-6 yaş grubu çocukların sosyal becerileri ile teknoloji kullanımları arasındaki ilişkinin incelenmesidir. Araştırmanın çalışma grubunu 4-6 yaş aralığında olan 298 çocuk oluşturmaktadır. Araştırmada veri toplama aracı olarak Sosyal Becerileri Değerlendirme Ölçeği, Okul Öncesi Çağındaki Çocukların Teknoloji Kullanımı Hakkındaki Ebeveyn Görüşleri Anketi ve kişisel bilgi formu kullanılmıştır. Verilerin analizinde değişkenler arasındaki ilişkiyi incelemek için Spearman's Brown sıra farkları korelasyon katsayısı analiz tekniği kullanılmıştır. Araştırmanın sonucunda çocukların sosyal becerileri ile ebeveynlerin çocukların teknolojinin kullanımına yönelik önerileri arasında düşük düzeyde pozitif ve negatif yönlü ilişkiler olduğu görülmüştür. Bulgular doğrultusunda çeşitli önerilerde bulunulmuştur.

Anahtar Kelimeler: Okul öncesi, sosyal beceri, teknoloji kullanımı.

\section{Abstract}

The aim of this study is to investigate the relationship between the social skills of children aged 4-6 and the use of technology in preschool education. The study group consisted of 298 children aged 4-6 years. In the study, Social Skills As-sessment Scale, Parents' Opinion on Technology Use of Child-ren in Preschool Age Survey and personal information form were used as data collection tools. In the analysis of data, Spearman Browns sequence difference correlation coefficient analysis technique was used to examine the relationship between variables. As a result of the research, it was seen that there were low positive and negative relations between the social skills of children and the suggestions of parents about the use of technology by children. According to the findings, various suggestions were made.

Keywords: Preschool, social skills, technology use.

\footnotetext{
${ }^{1}$ Bu çalışma birinci yazarın yüksek lisans tezinden üretilmiştir.

${ }^{2}$ MEB, İstanbul, Türkiye. https://orcid.org/0000-0001-8601-2819

${ }^{3}$ Kastamonu Üniversitesi, Eğitim Fakültesi, Temel Eğitim Bölümü, Kastamonu, Türkiye. https://orcid.org/0000-0003-0749-2688

${ }^{4}$ Sorumlu Yazar: İnönü Üniversitesi, Eğitim Fakültesi, Temel Eğitim Bölümü, Malatya, Türkiye. https://orcid.org/0000-0002-8442-354X Atıf / Citation: Özcan, F., Çağlar, A., \& Pekdoğan, S. (2020). 4-6 yaş grubu çocukların sosyal becerileri ve teknoloji kullanımları arasındaki ilişkinin incelenmesi. Kastamonu Education Journal, 28(2), 709-717. doi:10.24106/kefdergi.697168
} 


\section{Extended Abstract}

Purpose: Considering the impact of technology on children's developmental areas and studies in the literature, there is no study in-vestigating the relationship between social skills and technology use of children aged 4-6 years. In this context, supporting children's social skills development in preschool years, along with affecting other areas of development, is an important issue in establishing healthy and acceptable relations with social environment in later life. As a matter of fact, research show that children's development areas are progressing by supporting each other. The effect of environment and mass media on brain development at early ages affects brain function in later ages (Başal, 2005). In this study, it was aimed to investigate the relationship between social skills and technology usage of 4-6 age group children.

Method: In this study, the relational scanning method was used in the descriptive survey model as it was aimed to examine the rela-tionship between the social skills of 4-6 age group and their use of technology. The participant of this study consists of 2134 children aged 4-6 years who attend pre-school education in 2015-2016 academic year in central district of Amasya. The sample of the study consisted of 298 children in total aged between 4-6 years, 143 girls and 155 boys attending pre-school education in 5 different state kindergartens in Amasya city center which was determined by the appropriate sampling method. The appropriate sampling method is the sampling method which provides practicality and convenience to researchers in terms of accessibility of data sources, data acquisition, time and financial means (Creswell, 2012).

Social Skills Assessment Scale (SBDÖ) developed by Avcıoğlu (2007) and Parents' Opinion on the Technology Use of Preschool Children developed by Kılınç (2015) and personal information form as a data collection tool were applied in accordance with the volun-tariness principle and by taking necessary permissions.

For the application part of the study, permission procedures have been started for the schools where Amasya Provincial Directorate of National Education is responsible for and interviewed with administrators and teachers after taking necessary permits. Before the data were collected, teachers were informed about the thesis topic and scales. 600 questionnaires were distributed to the teachers in the scho-ols and they were asked to send parents at the same time. However, 330 of these questionnaires were handed in and 298 of these questi-onnaires were included in the study.

The data were analyzed by SPSS statistical package program. The normality test was applied to test the normalization of the distribu-tion of the obtained data. According to the results of normality test, there was no normal distribution of data for both tests $(s d=297, p=.031<.05 ; s d=297, p=.001<.05)$. In addition to this, the coefficient value of the data obtained with the SCSS scale is -.019 and the printing coefficient value is -.397; The skewness coefficient value of the data obtained with the TKEGA scale was .743 and the kurtosis coefficient value was 5.440. According to these results, it is concluded that the data obtained from both tests do not have normal distri-bution. Spearmanis Brown sequence difference correlation coefficient analysis technique was used to examine the relationship between technology use and social skills of pre-school children.

Findings: As a consequence of the study, it was seen that there was a low level negative-oriented correlation( $r=-, 132, p<, 05)$ between interpersonal skills and recommendations. Furthermore. it was seen that there was low level negative-oriented correlation between the ability to control of frustration behaviours and to adapt to alterations and recommendations. $(r=, 165$, $p<, 05)$ whereas there was low llevel positive-oriented correlation between self-control skills and recommendations ( $r=122$, $p<, 05)$ and in the total of the technology scale $\left(r 0,195^{* *}, p<01\right)$. Besides, it was observed that there was low level negativeoriented correlation the ability of purpose setting skills $(r=-, 136, p<05)$, and task compeltion and recommendations $(r=-, 191$, $p<01)$ as it was in the case of ability to accept the results and to use technology $(r=-, 141, p<, 05)$ but there was low level negativeoriented correlation in the total of technology scale $\left(=, 121^{* *}, p<01\right)$. However $(r=-, 134, p<, 05)$ it was seen that there was low level negative-oriented correlation between recommendati-ons and the total of the social skill scale. In general,it was seen that there was low correlation between social skill of children and pa-rents' suggestions fort he use of technology.

Discussion: In the light of these findings, children's interpersonal skills, ability to control anger behaviors and adaptation to chan-ges, skills to complete tasks, ability to accept results and parents' recomendations to use of technology show increase/decrease related to social skills scale increasing / decreasing. When the literature was examined, it was seen that 66\% of the parents were connected to the internet with the mobile device at home. In this period, as a result of parents' lack of interest and love for their children and mixed roles of the individuals in the family, the children tend to the use of internet and mobile devices; and thus, the more Internet leads to break the communication, the more it leads to vicious cycle (Sezgin and Tonguc, 2016). Therefore, when the parents' suggestions for the use of technology are examined, it can be thought that the reasons for having a negative relationship in many dimensions are that parents spend more time on the Internet and that technological tools are seen as a means of distracting children.

In a study, it was found that the social development of children who spent most of their time using internet and playing computer games receded significantly, their self-confidence was low, social anxiety levels and aggressive behaviors were high (Holman et al, 2005). Excessive use of computers and the Internet affects the psycho-social development of the child adversely. For the development of healthy personality, the interaction of the child with the family members and their peers, who are in the social environment, is replaced by electronic friendship and this situation affects the social skills of interpersonal 
communication and communication skills negatively (Caplan, 2002). Another finding of the study is that there is a positive and meaningful relationship among the skills of the children to control themselves, parents' suggestions for technology use and the ability to accept the results. It can be interpreted that the more the increase in acceptance results level after events and their self control skills, the more skills of using technology of children increases when children have more guidance in the family about use of technology and children's ability to use technology increases. Since this study is the first in the literature, it has limitations in comparison with other studies.

Recomendations: According to the findings of the study, parents with preschool children are advised to receive in-service training on the correct use of technological devices for children. Parental awareness is of paramount importance. Qualitative and quantitative studies on the impact of technological tools on social emotional development of children can be contributed to the literature. A similar study can be conducted on different sample groups. In addition, it is an important issue that the pre-school teachers should be educated about the use of technology and awareness of the families should be emphasized. 


\section{Giriş}

Çocuğun doğduğu günden temel eğitime başladığı güne kadar geçen yılları kapsayan ve çocukların daha sonraki yaşamlarında önemli roller oynayan süreç, okul öncesi dönem olarak adlandırımaktadır. Bu dönemde çocuğun bedensel, motor, sosyal-duygusal, zihinsel ve dil gelişimleri büyük ölçüde tamamlanmaktadır. Bu gelişim alanlarının desteklenmesi, kişiliğin şekillenmesi ve geleceğin istendik bireylerinin yetiştirilebilmesi için ailelerde ve kurumlarda verilen eğitim ise okul öncesi eğitim olarak tanımlanmaktadır (Aral, 2000). Tuğrul (2006) okul öncesi eğitimi, bu dönem çocuğunun çok boyutlu gelişimini destekleyen, yaşam boyu sürecek öğrenmenin temelinin atıldığı, sistemli ve bilinçli bir eğitim süreci olarak ifade etmektedir. Okul öncesi çocuğunun gelişim hızı ve öğrenme kapasitesi yüksektir. Bu dönemin kendine has büyüme ve gelişim özelliklerinin olduğu çocuk psikolojisi alanı ile ilgili çeşitli teorilerin ortaya konulduğu görüşlerle vurgulanmış ve özellikle okul öncesi çocuğunun bireysel özelliklerinin farkında olarak yapılan eğitimin önemine değinilmiştir. Okul öncesi eğitim; sosyoekonomik ve kültür düzeyleri farklı olan ailelerin çocuklarının eşit şartlarda eğitim almalarına imkân vererek, gelişimlerinin her alanında yeteneklerinin farkına varılmasını sağlar (Oktay, 2005). Okul öncesi eğitim süresinde çocuklar gelişim alanlarına ilişkin bir takım beceriler edinmektedirler. Özellikle sosyal duygusal alandaki beceriler desteklendiği zaman çocuklar, bağımsızlığını kazanmış, olumlu ilişkiler kurabilen, özgüvenli, kendisinin farkında, üretken, kendisi ve çevresiyle barışık bireyler olarak toplumda yerini almaktadırlar (Zembat, 2005).

Çocuğun toplumla uyum içerisinde yaşamasını sağlayan beceriler, sosyal beceriler olarak adlandırılmaktadır. Sosyal beceriler bireyin diğer insanlarla iletişim kurmasını kolaylaştıran becerilerdir (Avcıoğlu, 2005; Avşar ve ÖztürkKuter, 2007). Gülay ve Akman (2009), sosyal becerileri sosyal ilişkileri başlatıp, devamını sağlayan, bu ilişkilerde yaşanan sorunların çözümünde yapıcı etki sağlayan sözel ya da sözel olmayan davranışlar olarak tanımlamışlardır. Paylaşma, yardımlaşma, ilişkiyi başlatma, diğer kişilerden yardım talep etme, hayranlık ve saygı gibi duyguları ifade edebilme," lütfen" ve "teşekkür ederim" gibi nezaket sözcüklerini kullanabilme arzu edilen beceriler olmakla birlikte, sosyal becerilerin genel olarak kabul gören özellikleridir (Gresham ve Elliott, 1993; Bilton ve Bonnet, 2008). Çocukların kazandığı sosyal beceriler sosyal gelişimlerini etkilemektedir. Sosyal gelişim ise çocukların ailesiyle, akranlarıyla ve çevresindeki diğer bireylerle olan ilişki ve etkileşimlerini, sorumluluk alma, işbirliği, paylaşma gibi sosyal becerilerin kazanımını içeren bir süreçtir. Bu süreç içerisinde, çocuğun içerisinde bulunduğu sosyal çevredeki işlevselliğini geliştirebilmesinde ise sosyal becerilerinin desteklenmesi önem taşımaktadır. Nitekim çocuğun duyguları, beklentileri, çevresindeki bireylerin çocuktan neler beklediği, çocuğun sergilemiş olduğu bir davranışın sebep ve sonuçlarını ifade edebilme becerisi, çevresiyle kurduğu etkileşimde önemli rol oynamaktadır (Ömeroğlu ve Ulutaş, 2007).

Çocuk sosyal becerileri edinirken çevresindeki birçok faktörün etkisi altında girmektedir. Özellikle aile, akran, yaş, cinsiyet, kardeş ve oyun gibi etkenlerin yanı sıra kitle iletişim araçları da çocukların sosyal becerileri üzerinde önemli etkilere sahiptir. Okul öncesi dönemde özellikle çocuklar üzerinde etkili kitle iletişim araçları televizyon ve tablet-bilgisayar kullanımıdır. Televizyonda yer alan programlar ve bilgisayar-tablet içeriğindeki videolar çocukların; işbirliği, yardımlaşma, öfke kontrolü, üzüntüyle başa çıkabilme, sorumluluklarını yerine getirme gibi olumlu davranışları ve dil becerilerini ya da ısırma, vurma, saldırganlık gibi olumsuz davranışlarını destekler nitelikte olabilir. Televizyonun çocuklar üzerinde olumlu etkilerinin olması, çocukların izlediği programın niteliğine, izlenen kahramanların olumlu davranış modelleri geliştirmesine bağlıdır. Okul öncesi dönemde çocukların özellikle ilgilerini çizgi film kahramanları çekmekte ve çizgi filmlerdeki kahramanlarla rol modeli alarak onlarla özdeşim kurmaktadırlar. Olumsuz davranış modelleri çocukların olumsuz davranışlar sergilemesine neden olabileceğinden bu kahramanların olumlu rol modeli olmaları önemlidir. Aynı zamanda uzun süre televizyon ve bilgisayar başında kalmak, çocukların çevreye ilgisiz kalmalarına, sosyal becerileri öğrenme ve uygulama imkânlarının kısıtlanmasına neden olabilmektedir (Özcan ve Buzlu, 2005).

Alan yazın incelendiğinde çocuklarda teknoloji kullanımının gelişim alanları üzerindeki etkisine yönelik çeşitli bulguların yer aldığı görülmektedir. Erken çocukluk döneminde, teknolojik araçların kullanımı, fiziksel, zihinsel ve psikolojik ve sağlık problemlerini ortaya çıkarmaktadır. Bunlar, obezite, tembellik, uykuculuk, saldırganlık ve dikkat eksikliği olarak karşılaşılan problemlerdir (Nunez-Smith, Wolf, Huang, Emanuel, \&Gross, 2008). Rideout\& Hamel (2006), televizyon gibi araçların evlerinde daha çok kullanıldığı çocukların daha az kullanılan çocuklara göre okumayı daha geç öğrendiklerini belirtmektedirler. Erken çocukluk döneminde teknoloji kullanımının olumsuz etkilerini yanı sıra olumlu etkileri olduğunu belirten çalışmalar da alan yazında yer almaktadır. Bilgisayarlarla desteklenmiş eğitim, çocukların merak duygusunu artırmakta, böylece çocukların ilgi ve isteklerini dikkate alarak gerçekleştirilen bir eğitim 
içinde öğrenme daha etkili hale getirmektedir (Aral, 2000). NAEYCF (2012) ise teknolojik araçların çocuklardaki olumlu etkilerinin dil ve kelime hazinesinde gelişmeler, mantık matematiksel anlayış, problem çözme becerileri, kendini yönetme ve sosyal becerilerde gelişmeyi sağlama olarak belirlemektedir. Teknolojinin çocukların gelişim alanları üzerindeki etkisi ve alan yazındaki çalışmalar göz önüne alındığında, 4-6 yaş aralığındaki çocukların sosyal becerileri ve teknoloji kullanımları arasındaki ilişkiyi inceleyen çalışmaya rastlanılmamıştır. Bu bağlamda okul öncesi yıllarda çocuğun sosyal beceri gelişiminin desteklenmesi, gelişiminin diğer alanlarını da etkilemekle birlikte, yaşamının ileriki dönemlerinde sosyal çevre ile sağlıklı ve kabul edilebilir ilişkiler kurabilmesinde önemli bir husus olmaktadır. Nitekim yapılan araştırmalar çocukların gelişim alanlarının birbirlerini destekleyerek ilerlediğini göstermektedir. Erken yaşlarda çevrenin ve kitle iletişim araçlarının beyin gelişimi üzerindeki etkisi, ileriki yaşlardaki beyin fonksiyonlarını da etkilemektedir (Başal, 2005). Bu doğrultuda çalışmada 4-6 yaş grubu çocukların sosyal becerileri ve teknoloji kullanımları arasındaki ilişkinin incelenmesi amaçlanmıştır.

\section{Yöntem}

\section{Araştırmanın Modeli}

Araştırmada, 4-6 yaş grubu çocukların sosyal becerileri ile teknoloji kullanımları arasındaki ilişkinin incelenmesi amaçlandığından, betimsel tarama modelinde ilişkisel tarama yöntemi kullanılmıştır. Araştırmada bu modelin kullanılmasının sebebi, ilişkisel araştırma modelinin, araştırılmak istenen konudaki durumları betimlemenin dışında, değişkenlerin aralarında ne şekilde bir ilişki bulunduğunu öğrenmemize yardımcı olarak olguları güçlü bir şekilde anlamamıza olanak vermesidir (Büyüköztürk, Kılıç-Çakmak, Akgün, Karadeniz ve Demirel, 2013).

\section{Çalışma Grubu}

Bu araştırmanın evrenini Amasya ili Merkez ilçesinde bulunan 2015-2016 eğitim öğretim yılında okul öncesi eğitime devam eden 4-6 yaş 2134 çocuk oluşturmaktadır. Araştırmanın örneklemini ise Uygun Örneklem yöntemi ile belirlenmiş olan, Amasya İli Merkez ilçesindeki devlete bağlı 5 farklı resmi bağımsız anaokulunda okul öncesi eğitime devam eden 4-6 yaş aralığındaki, 143 kız, 155 erkek toplam 298 çocuk oluşturmuştur. Uygun örneklem yöntemi, veri kaynaklara erişilebilirlik, verilerin elde edilmesi, zaman, maddi imkânlar açısından araştırmacılara pratiklik ve kolaylık sağlayan örneklem yöntemidir (Creswell,2012). Bu araştırmada, ilgili anaokullarına erişilebilirlik, çalışmanın yürütülmesi açısından kolaylıklar sunması, kurumların yakın olması örneklem seçiminde belirleyici olmuştur. Araştırmaya katılan örneklem grubuna ilişkin özellikler Tablo 1.de verilmiştir.

Tablo 1.Araştırma Grubunun Demografik Özellikleri

\begin{tabular}{|c|c|c|c|}
\hline Demografik Özellikler & Özelliklerin Boyutu & $f$ & $\%$ \\
\hline \multirow{4}{*}{ Çocukların Yaşı } & 4 & 47 & 15,8 \\
\hline & 5 & 130 & 43,6 \\
\hline & 6 & 121 & 40,6 \\
\hline & Toplam & 298 & 100 \\
\hline \multirow{3}{*}{ Çocukların Cinsiyeti } & $\mathrm{K} ı \mathrm{Z}$ & 135 & 45,3 \\
\hline & Erkek & 163 & 54,7 \\
\hline & Toplam & 298 & 100 \\
\hline \multirow{4}{*}{$\begin{array}{l}\text { Okul Öncesi Eğitime Devam } \\
\text { Süresi }\end{array}$} & $1 \mathrm{yll}$ & 155 & 52,0 \\
\hline & $2 \mathrm{yll}$ & 98 & 32,9 \\
\hline & 3 yıl ve Üzeri & 45 & 15,1 \\
\hline & Toplam & 298 & 100 \\
\hline \multirow{6}{*}{ Anne Eğitim Seviyesi } & illkokul & 43 & 14,4 \\
\hline & Ortaokul & 41 & 13,8 \\
\hline & Lise & 100 & 33,6 \\
\hline & Üniversite & 102 & 34,2 \\
\hline & Lisansüstü & 12 & 4,0 \\
\hline & Toplam & 298 & 100 \\
\hline \multirow{6}{*}{ Baba Eğitim Seviyesi } & ilkokul & 32 & 10,7 \\
\hline & Ortaokul & 31 & 10,4 \\
\hline & Lise & 121 & 40,6 \\
\hline & Üniversite & 92 & 30,9 \\
\hline & Lisansüstü & 22 & 7,4 \\
\hline & Toplam & 298 & 100 \\
\hline \multirow{3}{*}{ Kardeş Sayısı } & Tek Çocuk & 84 & 28,2 \\
\hline & 1 kardeş & 166 & 55,7 \\
\hline & 2 kardeş & 45 & 15,1 \\
\hline
\end{tabular}




$\begin{array}{lll}3 \text { ve üstü } & 3 & 1,0 \\ \text { Toplam } & 298 & 100\end{array}$

Tablo 1. incelendiğinde araştırmaya katılan çocukların 47'si $(\% 15,8) 4$ yaşında, 130'u $(43,6) 5$ yaşında, 121'i (\%40.6) 6 yaşındadır. Çocukların 135'i $(45,3)$ kız, 163'ü $(54,7)$ 'si erkektir.

\section{Veri Toplama Araçları}

Araştırmada veri toplama aracı olarak Avcıoğlu (2007) tarafından geliştirilen (SBDÖ) "Sosyal Becerileri Değerlendirme Ölçeği” ve Kılınç (2015) tarafından geliştirilen “Okul Öncesi Çağındaki Çocukların Teknoloji Kullanımı Hak-kındaki Ebeveyn Görüşleri Anketi” ve kişisel bilgi formu gerekli izinler alınarak ve gönüllük ilkesine uygun olarak uy-gulanmıştır.

Sosyal Becerileri Değerlendirme Ölçeği (SBDÖ): SBDÖ okul öncesi dönemdeki 4-6 yaş çocukları için (Avcıoğlu, 2007) tarafından geliştirilmiştir. Ölçek 62 madde ve 9 alt ölçekten oluşmakta ve beşli likert tipidir. Alt ölçekler; Kişiler Arası Beceriler (KAB), Kızgınlık Davranışlarını Kontrol Etme ve Değişikliklere Uyum Sağlama Becerileri (KDKEDUSB) Akran Baskısı ile Başa Çıkma Becerileri (ABBÇB), Kendini Kontrol Etme Becerileri (KKEB), Sözel Açıklama Becerileri (SAB), Sonuçları Kabul Etme Becerileri (SKEB), Dinleme Becerileri (DB), Amaç Oluşturma Becerileri (AOB) ve Görev-leri Tamamlama Becerileridir (GTB). Ölçek 4-6 yaş arası çocukların sahip oldukları sosyal beceriler, belirtilen alt boyut-lar dahilinde ölçmeyi amaçlamaktadır. Ölçme arası sınıf öğretmenleri tarafından doldurulmaktadır. Güvenilirliği belirlemek amacıyla Cronbach Alfa iç tutarlıık katsayısı, iki yarım güvenilirliği, tekrar test güvenilirlikleri hesaplanmış Cronbachalpha güvenirlik katsayısı;.98, iki yarım güvenirlik katsayısı.89 ve test-tekrar test güvenirlik katsayısı ise,.83 olarak bulunmuştur (Avcoğlu, 2007).

Okul Öncesi Çağındaki Çocukların Teknoloji Kullanımı Hakkındaki Ebeveyn Görüşleri Anketi (TKEGA): TKEGA, okul öncesi dönemdeki çocukların teknoloji kullanımı hakkında bilgi edinmek amacıyla Kılınç (2015) tara-fından geliştirilmiştir. Ölçek 25 madde ve 6 alt ölçekten oluşmaktadır ve likert tipidir. Teknoloji Kullanımında Aile Rehberliği (TKAR), Teknolojinin Faydaları (TF), Teknoloji Kullanma Alanları (TKA), Teknolojinin Zararları (TZ), Tek-noloji Kullanma Becerisi (TKB) ve Öneriler (TÖN) alt boyutları ve görüşleri ve okul öncesi çağındaki çocuklar ve ailele-rinin teknolojik alet kullanım sıklığı olmak üzere toplam iki bölümden meydana gelmektedir. Yapılan analizler sonu-cunda ölçeğin Cronbach Alpha iç tutarlılık katsayısının .73 olduğu sonucuna ulaşılmıştır (Kılınç, 2015).

Kişisel Bilgi Formu: Kişisel bilgi formu çocukların yaş, cinsiyeti okul öncesi eğitime devam süreleri, anne-baba eğitim seviyesi ve kardeş sayısı bilgilerini edinmek amacıyla araştırmacılar tarafından oluşturulmuştur. Bilgiler çocukların okuldaki kişisel dosyalarından alınmıştır.

\section{Verilerin Toplanması}

Araştırmanın uygulama kısmı için Amasya İ Milli Eğitim Müdürlüğü’ne uygulamanın yapılacağı okullar için izin işlemleri başlatılmış, gerekli uygulama izinleri alınarak, belirlenen okullara gidilip idareci ve öğretmenlerle görüşülmüştür. Veriler toplanmadan önce okullardaki öğretmenlere çalışmanın konusu ve ölçme araçları hakkında bilgi verilmiştir. Okullarda bulunan öğretmenlere 600 adet ölçme aracı dağıtılmış, eş zamanlı olarak da çocukların ailelerine göndermeleri istenmiştir. Fakat ölçme araçlarından 330'u geri dönmüş, eksiksiz tamamlanan 298 ölçme aracı çalışmaya dâhil edilmiştir.

Sistematik şekilde yanıtlamalar yapıldığında (örneğin tüm maddeleri 5 işaretlemek gibi) ve \%5'ten fazlasının boş bırakılması durumunda ilgili verilerin analiz dışı bırakıldığı bilinmektedir (Kaya, 2015). Bu nedenle, veriler toplandık-tan sonra, öğretmen ya da ebeveynlerin 32 ölçekteki her maddeyi ya da önemli bir kısmını boş bırakmaları nedeniyle bu veriler çalışmaya dâhil edilmemiştir. Eksiksiz doldurulduğu belirlenen 298 anket formu bu çalışmaya dâhil edilmiştir

\section{Verilerin Analizi}

Elde edilen veriler SPSS istatistik paket programı ile analiz edilmiştir. Elde edilen verilerin dağılımın normalliğinin test edilmesi için normallik testi uygulanmıştır. Normallik testi sonuçlarına göre her iki test açısından da verilerin normal dağılım göstermediği ortaya çıkmıştır ( $s d=297, p=.031<.05 ; s d=297, p=.001<.05)$. Bunun yanında SBDÖ ölçeği ile elde edilen verilere ait çarpıklık katsayı değeri -.019, basıklık katsayı değeri ise -.397 olarak; TKEGA ölçeği ile elde edilen verilere ait çarpıklık katsayı değeri .743 ve basıklık katsayı değeri ise 5.440 olarak bulunmuştur. Bu sonuçlara göre her iki testten elde edilen verilerin normal dağııma sahip olmadığı sonucuna ulaşılmıştır. Okul öncesi eğitim alan çocukların teknoloji kullanımı ve sosyal becerileri arasındaki ilişkiyi incelemek için Spearman's Brown sıra farkları korelasyon katsayısı analiz tekniği kullanılmıştır. Spearman's Brown sıra farkları korelasyon katsayısı değişkenlerin normal dağııım göstermediği durumlarda iki değişken arasındaki ilişkiyi açıklamak amacıyla kullanılmaktadır (Büyüköztürk, 2013). 


\section{Bulgular}

4-6 yaş grubu çocukların sosyal becerileri ve teknoloji kullanımları arasındaki ilişkiyi incelemek amacıyla Spearman's Brown sıra farkları korelasyon katsayısına bakılmış ve bulgular Tablo 2.'de verilmiştir.

Tablo 2. 4-6 yaş grubu çocukların sosyal becerileri ve teknoloji kullanımları arasındaki ilişkiye yönelik Spear-man's Brown sıra farkları korelasyon katsayısı bulguları

\begin{tabular}{lccccccc}
\hline Değişkenler & TKAR & TF & TKA & TZ & TKB & TÖN & TTOP \\
\hline KAB &, 070 &,- 070 &, 007 &, 088 &, 060 &,$- 132^{*}$ &, 039 \\
KDKEDUSB &, 060 &,- 037 &, 005 &, 066 &, 066 &,$- 165^{* *}$ &, 057 \\
ABBÇB &, 067 &,- 001 &, 061 &,- 002 &, 048 &,- 107 &, 062 \\
SAB &,- 017 &,- 010 &, 026 &,- 004 &, 061 &,$- 152^{* *}$ &, 031 \\
KKEB &, 112 &, 058 &, 092 &, 084 &, 100 &, $122^{*}$ &, $195^{* *}$ \\
AOB &, 053 &, 028 &, 023 &, 068 &, 086 &,$- 136^{*}$ &, 096 \\
DB &, 030 &,- 063 &, 007 &, 095 &, 054 &,- 042 &, 046 \\
GTB &, 066 &,- 095 &,- 022 &, 084 &,- 003 &,$- 191^{* *}$ &,- 012 \\
SKEB &, 106 &,- 003 &, 044 &, 080 &, $141^{*}$ &, 092 &, $121^{*}$ \\
SBDÖTOP &, 082 &,- 055 &, 018 &, 092 &, 076 &,$- 134^{*}$ &, 069 \\
\hline
\end{tabular}

${ }^{* *} \mathrm{p}<, 01, * \mathrm{p}<, 05$

Tablo 2.'de yer alan bulgular incelendiğinde, kişilerarası becerileri (KAB) ile Öneriler (TÖN) $(r=-, 132, p<, 05)$ arasında düşük düzeyde, negatif yönlü korelasyon olduğu görülmüştür. Kızgınlık davranışlarını kontrol etme ve değişikliklere uyum sağlama becerileri (KDKEDUSB) ile Öneriler (TÖN) $(r=-, 165, p<, 05)$ arasında düşük düzeyde, negatif yönlü, kendini kontrol etme becerileri (KKEB) ile Öneriler (TÖN) $(r=, 122, p<, 05)$ ve teknoloji ölçeği toplamında $\left(r=, 195^{* *}, p<01\right)$ düşük düzeyde pozitif yönlü, amaç oluşturma beceriler (AOB) ile Öneriler (TÖN) ( $r=-$ ,136, $p<, 05)$, görevleri ta-mamlama becerileri (GTB) ile Öneriler (TÖN) $(r=-, 191, p<, 01)$ arasında düşük düzeyde negatif yönlü, sonuçları kabul etme becerileri (SKEB) ile teknoloji kullanma becerisi (TKB) $(r=-, 141, p<, 05)$ arasında düşük düzeyde negatif yönlü ve teknoloji ölçeği toplamında $\left(r=, 121^{* *}, p<01\right)$ düşük düzeyde pozitif yönlü, sosyal beceri ölçeği toplamında (SOSTOP) ve öneriler (TÖN) arasında ise $(r=-, 134, p<, 05)$ düşük düzeyde negatif yönlü ilişki olduğu görülmüştür. Genel olarak incelendiğinde çocukların sosyal becerileri ile ebeveynlerin çocukların teknolojinin kullanımına yönelik önerileri ara-sında düşük düzeyde iliş̧i olduğu görülmüştür.

\section{Sonuç ve Tartışma}

Günümüzde teknoloji kullanım alanlarının genişliği, ebeveynlerinde sorumluluk alanlarının genişletmektedir. Bu bağlamda çalışmada okul öncesi eğitime devam eden 4-6 yaş aralığındaki çocukların sosyal becerileri ile teknoloji kullanımları arasındaki ilişki incelenmiştir. Çalışmanın sonucunda çocukların kişilerarası becerileri, kızgınlık davranışlarını kontrol etme ve değişikliklere uyum sağlama becerileri, amaç oluşturma becerileri, görevleri tamamlama becerile-ri, sonuçları kabul etme becerileri ve sosyal beceri ölçeğinin toplamı ile ebeveynlerin çocukların teknolojinin kullanımı-na yönelik önerileri arasında düşük düzeyde negatif yönlü ilişki olduğu görülmüştür. Bu bulgular doğrultusunda çocuk-ların kişilerarası becerileri, kızgınlık davranışlarını kontrol etme ve değişikliklere uyum sağlama becerileri, görevleri tamamlama becerileri, sonuçları kabul etme becerileri ve sosyal beceri ölçeğinin arttıkça/azaldıkça ebeveynlerin tek-noloji kullanımına yönelik önerlileri artış/azalış göstermektedir. Alan yazın incelendiğinde, ebeveynlerin \%66'sının evinde mobil cihazla internete bağlandığı görülmüştür. Bu süre de ebeveynlerin çocuklara ilgi ve sevgi göstermemesi, aile içindeki bireylerin rollerinin karışması sonucu çocuğun daha çok mobil cihazlara ve internete yönelmesi bunun da iletişimi daha çok koparmaya götürmesi şeklinde kısır döngüye neden olmaktadır (Sezgin ve Tonguç, 2016). Dolayı-sıyla ebeveynlerin çocukların teknoloji kullanımına yönelik önerileri incelendiğinde birçok boyutta negatif yönlü ilişki-nin olmasının nedeni olarak, ebeveynlerin internette fazla vakit geçirmesi ve teknolojik araçların çocukları oyalama aracı olarak görülmesinden kaynaklandığı düşünülebilir.

Okul öncesi dönemde çocukların sosyal becerilerini etkileyen faktörlerden en önemlisi ebeveynlerdir. Çocuğun ailesi ile olan ilişkileri, yaşam boyunca sergileyeceği tutum ve davranışların temelini oluşturmaktadır. Cep telefonu, tablet ve bilgisayarlar çocuklarda çizgi film ve çeşitli videoları izlemek amacıyla kullanılmaktadır. Uzun süre bu aletlere kanali-ze olan çocuklar, dikkatini tek bir yöne odaklamakta, dış dünya ile olan iletişimlerini sınırlandırmaktadırlar. Bu nok-tada ebeveynlerin çocuklara yönelik tutum ve davranışları sosyal beceriler üzerinde etkili olmaktadır. Çocukların 
televizyon izleme, tablet, cep telefonu ve bilgisayar kullanımları gelişim alanları üzerinde olumlu ve olumsuz etkiler yaratabilmektedir. Çocuklarda özellikle sosyal geri çekilme, teknoloji kullanımının olumsuz etkileri içerisinde yer almaktadır (Epstein, 2015). Aşırı olmadığı sürece oynanan oyunlar ve izlenen videolar çocuklarda olumlu etkiler yaratabilmekte, fakat ebeveyn kontrolünde olmayan, bilinçsizce kullanımlar bilişsel ve dil gelişimi üzerinde de olumsuz etkiler yaratabilmektedir (Akkoyunlu \& Tuğrul, 2002). Benzer şekilde Colwell ve Kato (2003); Kubey, Lavin ve Barrows (2001), çocuklarda teknoloji kullanımının problem çözme, yaratıcılık, bilgiye erişme gibi becerileri geliştirdiği gibi, kontrolsüz ve bilinçsiz kullanımda endişe ve korkulara neden olarak çocukların kişilik gelişimini olumsuz etkilediğini belirtmektedirler.

Yapılan bir çalışmada zamanının çoğunu internet kullanarak ve bilgisayar oyunları oynayarak geçiren çocukların sosyal gelişimlerinin önemli ölçüde gerilediği, bu çocukların öz güvenlerinin düşük, sosyal endişe düzeylerinin ve saldır-ganlık davranışlarının yüksek olduğu tespit edilmiştir (Harman, vd, 2005). Bilgisayar ve interneti fazla kullanmak çocuğun psiko-sosyal gelişimi de olumsuz etkilemektedir. Çocuğun sağlıklı kişilik gelişimi için sosyal çevresi olan aile bireyleriyle ve akranlarıyla olması gereken etkileşimi, yerini elektronik arkadaşlığa bırakmakta, bu durum ise kişilerarası iletişim ve iletişimi sürdürme becerisi olan sosyal becerilerini olumsuz yönde etkilemektedir (Caplan, 2002). Çalışmanın başka bir bulgusu da çocukların kendilerini kontrol etme becerileri ile ebeveynlerin çocukların teknolojinin kullanımına yönelik önerileri arasında, sonuçları kabul etme becerileri ile teknoloji ölçeğinin toplamında pozitif yönlü, anlamlı bir ilişki olduğu yönündedir. Bu sonuç çocukların teknoloji kullanımında ailelerin daha fazla rehberlik ettiğinde ve çocukların teknolojiyi doğru kullanma becerileri arttıkça, kendilerini kontrol etme becerileri ve olaylar sonrasında meydana gelen neticeleri kabul etme düzeylerinin artması olarak yorumlanabilir. Bu çalışma alan yazında ilk olma özelliği taşıdığından dolayı, diğer çalışmalarla kıyaslanma açısından sınırılıklar taşımaktadır.

\section{5. Öneriler}

Teknolojik aletler çocuğun yaşı ve gelişimsel düzeyi, ilgi ve ihtiyaçlarına, sosyal ve kültürel özelliklerine uygun ola-rak kullanılmalıdır (DaleMcManis \& Gunnewig, 2012, Aral ve Doğal Keskin, 2018). Özellikle ebeveyn kontrolünde olan ve bilinçli teknolojik araçların kullanımının, çocukla üzerindeki olumlu etkiler yaratması beklenmektedir. Çalışmanın bulgularına göre okul öncesi çocuğuna sahip ebeveynlerin, çocukların teknolojik aletleri doğru kullanımları konusunda, hizmet içi eğitim almaları önerilmektedir. Bu konuda ebeveynlerin bilinçlenmesi büyük bir önem taşımaktadır. Teknolojik alet kullanımın, çocukların sosyal duygusal gelişimlerine etkisi üzerine nitel ve nicel çalışmalar yapılarak, alan yazınına katkı sağlanabilir. Benzer bir çalışma farklı örneklem grupları üzerinde çalışılabilir. Ayrıca okul öncesi öğretmenlerinin de teknoloji kullanımına yönelik eğitim almaları sağlanarak, aileleri bilinçlendirmeleri de üzerinde durulması gereken önemli bir konudur.

\section{Kaynakça}

Akkoyunlu, B., \& Tuğrul, B. (2002). Okulöncesi çocukların ev yaşantısındaki teknolojik etkileşimlerinin bilgisayar okuryazarlığı becerileri üzerindeki etkisi. Hacettepe Üniversitesi Eğitim Fakültesi Dergisi, 23(23).

Aral, N. (2000). Çocuk gelişimi 2, İstanbul: YA-PA.

Avcıoğlu, H. (2005). Etkinliklerle sosyal beceri öğretimi. Ankara: Kök.

Avcıoğlu, H. (2007). Sosyal becerileri değerlendirme ölçeğinin (4-6 yaş) geçerlik ve güvenirlik çalışması. Abant Izzet Baysal Üniversitesi Eğitim Fakültesi Dergisi, 7(2), 87- 101.

Avşar, Z. \& Öztürk-Kuter, F. (2007). Beden eğitimi ve spor bölümü öğrencilerinin sosyal beceri düzeylerinin belirlenmesi (Uludağ Üniversitesi örneği). Eğitimde Kuram ve Uygulama, 3(2), 197-206.

Başal, H. A. (2005). Okul öncesi eğitim, İstanbul: Morpa.

Bilton, T. \& Bonnet, K. (2008). Sosyoloji. Ankara: Siyasal Kitabevi.

Büyüköztürk, Ş., Kılıç-Çakmak, E., Akgün, Ö. E., Karadeniz, Ş. ve Demirel, F. (2013). Bilimsel araştırma yöntemleri. (15. Baskı). Ankara: Pegem.

Büyüköztürk, Ş. (2013). Sosyal bilimler için veri analizi el kitabı istatistik, araştırma deseni SPSS uygulamaları ve yorum (18. Baskı). Ankara: Pegem.

Caplan, S. E. (2002). Problematic Internet use and psychosocial well-being: development of a theory-based cognitivebehavioral measurement instrument. Computers in human behavior, 18(5), 553-575. 
Colwell, J., \& Kato, M. (2003). Investigation of the relationship between social isolation, self-esteem, aggression and computer game play in Japanese adolescents. Asian Journal of Social Psychology, 6(2), 149-158.

Creswell, J. W. (2012). Planning, conducting, and evaluating quantitative and qualitative research. Boston: Pearson.

Gresham, F. M. ve Elliot, S. N. (1993). Social skills Intervention guide: systematic approachesto social skills training. Special Services in the Schools, 8(1), 137-158.

Epstein, A. S. (2015). Using technology appropriately in the preschool classroom. https://cciemedia.s3.amazonaws.com/exchangefocus/001-exchangefocus.pdf. adresinden 20.01.2019 tarihinde erişilmiştir.

Evren, S. \& Tonguç, G. (2016). Okul Öncesi Eğitimde Mobil Teknolojilerin Kullanılmasına Yönelik Örnek Bir Araştırma. Eğitim ve Öğretim Araştırmaları Dergisi, 5(34), 296-303.

Harman, J. P., Hansen, C. E., Cochran, M. E., \& Lindsey, C. R. (2005). Liar, liar: Internet faking but not frequency of use affects social skills, self-esteem, social anxiety, and aggression. CyberPsychology \& Behavior, 8(1), 1-6.

Kaya, i. (2015). Ergenlerin çocukluk dönemi istismar yaşantıları ile davranış problemleri ve psikolojik sağlamlıkları arasında ilişkinin incelenmesinde otomatik düşünceler ve bilişsel duygu düzenleme stratejilerinin aracı rolü. Yayımlanmamış Yüksek lisans tezi, Çukurova Üniversitesi Sosyal Bilimler Enstitüsü, Adana.

Kılınç, S. (2015). Okul öncesi çağındaki çocukların teknoloji kullanımı hakkında ebeveyn görüşlerinin incelenmesi. Yayınlanmamış yüksek lisans tezi. Dumlupınar Üniversitesi Eğitim Bilimleri Enstitüsü. Kütahya.

Kubey, R. W., Lavin, M. J., \& Barrows, J. R. (2001). Internet use and collegiate academic performance decrements: Early findings. Journal of communication, 51(2), 366-382.

NAEYCF (National Association for the Education of Young Children and Fred Rogers Center for Early Learning and Children's Media ) (2012). Technology and interactive media as tools in early childhood programs serving children from birth through age 8: A joint position statement. http://www.naeyc.org/files/naeyc/fi le/positions/PStechnologyWEB2.pdf adresinden 10,03.2019 tarihinde erişilmiştir.

Nunez-Smith, M., Wolf, E., Huang, H. M., Emanuel, D. J., \& Gross, C. P. (2008). Media and child and adolescent health: a systematic review. Washington, DC: Common Sense Media.

Oktay, A. (2005). Okul öncesi eğitimin önemi ve yaygınlaştırılması, İstanbul: Morpa.

Ömeroğlu, E. ve Ulutaş, ì. (2007). Çocuk ve ergen gelişimi. İstanbul: Morpa.

Özcan, N. \& Buzlu S. (2005). Problemli internet kullanımını belirlemede yardımcı bir araç: “internette Bilişsel Durum Ölçeği"nin üniversite öğrencilerinde geçerlik ve güvenirliği. Bağımlıık Dergisi. 6, 19-26.

Rideout, V. J., \& Hamel, E. (2006). The media family: Electronic media in the lives of infants, toddlers, preschoolers and their parents. Henry J. Kaiser Family Foundation.

Tuğrul, B. (2005). Çocuk gelişiminde anaokulu eğitiminin önemi, Bilim ve Aklın Aydınlığında Eğitim Dergisi, 62(6), 2528.

Zembat, R. (2005). Okul öncesi eğitimde nitelik, İstanbul: Morpa. 